\title{
VOCATIONAL INTERESTS AMONG POLISH AND SLOVENIAN STUDENTS OF MANAGEMENT
}

\author{
D. OCHNIK ${ }^{\mathrm{a}}$, A. ARZENŠEK
}

\author{
${ }^{a}$ University of Opole, Plac Staszica 1, 45-052 Opole, Poland \\ ${ }^{b}$ University of Primorska, Cankarjeva ulica 5, 6000 Koper, Slovenia
}

\begin{abstract}
As vocational interests are a stronger predictor of future vocational success than personality or IQ, it is important to understand the vocational interests of upcoming leaders. In this scientific paper we aimed at expanding the current understanding regarding the vocational interests variability across cultures and gender by analysing gender and nationality based differences among Polish and Slovenian samples. 226 undergraduate students enrolled at the Faculty of Management in Poland and in Slovenia took part in the study. The Vocational Potential Inventory was applied in the study. The gender differences were more evident in the Polish group, with Polish women having stronger pro-social interests compared to Polish men, while Polish men showed stronger interests in leadership. Within the Slovenian sample, no statistically significant differences in vocational interests emerged. Female students in general had higher pro-social and lower technical interests. Therefore, the gender effect reflected the stereotypical gender role, women - people orientated and men - things orientated. Concerning the nationality effect, there were three clusters revealed, showing differentiation with regard to nationality. The clusters consisted of a Slovenian female group, a Polish female group and a male group. This means that cultural differences are stronger in the female group compared to the male group. Clustering revealed the male group having the strongest technical interests and Polish women the weakest. Implications of results are provided.
\end{abstract}

Keywords: vocational interests, students, management, gender, nationality, culture, Vocational Potential Inventory, social norms, leadership interest, technical interest, Poland, Slovenia.

\section{Introduction}

Choosing the right vocation is an important developmental task that has to be tackled during adolescence and early adulthood. This is a sensitive process that has implications for the individual's future career options and well-being. In the process of deciding which higher education program to choose, students opt for one that is consistent with (among other factors) their vocational interests' profile.

Vocational interests are "relatively stable individual differences that influence behaviours through preferences for certain work activities and work environments" (van Iddekinge, Putka, \& Campbell, 2011, p. 14), and are a strong predictor of career-related outcomes (Almeida, Ahmetoglu, \& Chamorro-Premuzic, 2014; Vardarlı, Özyürek, Wilkins-Yel, \& Tracey, 2017; Volodina \& Nagy, 2016). For example, they play an important role in job satisfaction (Vock, Köller, \& Nagy, 2013), turnover (van Iddekinge, Roth, Putka, \& Lanivich, 2011), and long term employment 
patterns (Wille, Tracey, Feys, \& De Fruyt, 2014). Furthermore, in their meta-analytic study Nye, Su, Rounds and Drasgow (2012) showed that vocational interests are valid predictors of work and academic performance. Su, Rounds, \& Armstrong (2009) showed vocational interests predict gender differences in work preferences. Empirical findings also demonstrate interests are reliable predictors of academic persistence, academic success, and college graduation (Tracey \& Robins, 2006; Tracey, Allen, \& Robins, 2012).

Sociocultural factors have an impact on vocational interests of both genders (Ott-Holland, Huang, Ryan, Elizondo, \& Wadlington, 2013). According to Bubany and Hansen (2011) and Lechner, Sortheix, Obschonka, \& Salmela-Aro (2018), sociocultural factors (e.g., gender stereotypes, gender role, socialization) affect the development of vocational interests as well as choices individuals make regarding their vocation. Moreover, Lubinski (2000, p. 421) stated sex differences in interests are "perhaps the largest of all sex differences on major psychological dimensions.” Paessler (2015) and Babarović, Dević, \& Burušić (2019) hypothesized gender differences in vocational interests are also a major contributing factor to a gender diversity gap in occupation fields, still traditionally occupied by men (in particular the STEM disciplines - science, technology, engineering, and mathematics) (Botella, Rueda, López-Iñesta, \& Marzal, 2019).

As data originating from a single culture challenges the generalizability of research results (Ion, Nye, \& Iliescu, 2019), we aimed at expanding the current understanding regarding the vocational interests variability across cultures and gender by analysing gender differences among Polish and Slovenian samples. We investigated whether gender differences in vocational interests exist between Polish and Slovenian students of Management. It is important to understand what Management students expect from their career and what vocational interests they have in order to be able to support them (Stone, Padron, Wray, La Lopa, \& Olson, 2017). To date no studies have investigated vocational interests in the Slovenian sample of Management students. In addition, no comparisons have been made in career related constructs among Polish and Slovenian students of Management in order to study gender differences.

In order to understand the context of vocational interests among Polish and Slovenian students of Management, we first examine the vocational interests of young adults; we then present the relationship between gender social norms and vocational interests in order to explain gender differences in interests, and, thirdly, we analyse sociocultural context of vocational interests.

\section{Vocational Interests in Young Adults}

It is important to study vocational interests in young adults in order to understand their educational and career choices (Volodina \& Nagy, 2016) and to predict their vocational motives (Bergner, Kanape, \& Rybnicek, 2019). Individuals more likely choose work settings that are compatible with their personal characteristics (Almeida et al., 2014; Kowalski, Vernon, \& Schermer, 2017). Vocational interests are developed during childhood and adolescence but may change throughout life span. Research (Bounchard \& McGue, 2003; Chamorro-Premuzic, 2011) shows that 
development of vocational interests is in part influenced by genes but also by various sociocultural factors during childhood, adolescence and young adulthood. The Individual's experience in different interest-specific domains also plays an important role in the interests' development; the experience of success in a certain sphere reinforces interest in that sphere and a failure diminishes interest. An enhanced interest normally leads to further engagement in that sphere. This results in more congruent vocational interest profiles over the years (Vock et al., 2013; Hirschi, 2010).

Vocational interests become more stable with age (Paessler, 2015; Ion et al., 2019; Schultz, Connolly, Garrison, Leveille, \& Jackson, 2017). When individuals are in their late 20's, the development of vocational interests generally stabilizes. However, in this stability significant individual differences exist (Lubinski, Benbow, \& Ryan, 1995; Vock et al., 2013). As Low \& Rounds (2007) hypothesise, stabilisation of interests is connected to cognitive maturation, to influences from educational and vocational systems and to decreased restrictions from the environment.

\section{Gender Social Norms}

Research has shown that there is a divergence among men and women regarding vocation interests (Bagheri, Akmaliah, \& Pihie, 2014; Volodina \& Nagy, 2016; Nagy, Trautwein, Baumert, Köller, \& Garrett, 2006; Su et al., 2009; Ion et al., 2019). Typically, females prefer social and artistic activities, whereas males prefer conventional, realistic and investigative activities (Vock et al., 2013; Mustata, 2014; Ion et al., 2019). In their research, Lawson, Leeb, Crouter, \& McHale (2018) found that boys and men desired and entered male-typical vocations from middle childhood to young adulthood (girls and women were less gender-typical in vocational choices in young adulthood), suggesting that males were possibly restricting their vocations from childhood and that women and men might have different trajectories of their vocational aspirations' development.

The development of vocational interests is influenced by socialisation processes. Primary and secondary education, factors such as parental expectations, role modelling, educational experiences and exposure to media, may shape the individuals' view of what professional activity is expected and desired in the society. Social role theory implies that gender differences in vocational interests occur from different roles men and women have in the society (Bubany \& Hansen, 2011). While women may be traditionally encouraged in activities that involve caring for others, helping, counselling and teaching, men may be assigned to activities that involve working with objects and leadership. Role expectations may also differ for men and women in terms of women being less encouraged to pursue professions that involve working with objects and leadership, while men might not experience such restrictions. In line with this, a greater male diversity in vocational interests is expected in more traditional societies, while in a more egalitarian society smaller gender differences in the interests' variability are expected.

However, meta-analytic research findings indicate a decrease in gender differences in vocational interests across cohorts of individuals born in different decades (Bubany \& Hansen 2011; Hansen, 1988). Also Mustata (2014) did not support the existence of differences in gender-related vocational interests in the sample of adolescent students. 
Moreover, a considerable increase in enterprising interests of women was found (Bagheri et al., 2014). The tendency in modern society is to adopt attitudes irrespective of their biological gender (Mustata, 2014), so women and men can pursue a challenging profession or successfully integrate in the opposite sex dominated fields.

\section{Cultural Context of Vocational Interests}

Gender differences in vocational interests may vary across cultures according to culture-specific gender role expectations (Atitsogbe, Moumoulab, Rochata, Antoniettia, \& Rossier, 2018). Expectations regarding occupational choices may still be culturally bound. In their research, Ott-Holland, Huang, Ryan, Elizondo, \& Wadlington (2013) analysed how collectivism and gender egalitarianism moderate the relationship between interests and personality. In collectivistic cultures, individuals might sacrifice their personal goals for collective goals. Familial expectations and family history may dictate career choices of their members and not dispositions of individuals. Consequently, vocational interests of individuals in collectivistic cultures might be more shaped by family dynamics.

In a study by Ott-Holland, Huang, Ryan, Elizondo, \& Wadlington (2013) gender egalitarianism was defined as the degree of gender inequality and gender stereotypes in a culture. It is assessed by a degree of gender equality in encouraging educational paths and professional development. In more gender egalitarian societies, women are not restrained from certain male-dominated careers, but this is not necessarily mirrored in female dominated professions being adopted by men, as shown by Wood \& Eagly (2010). In contrast, less gender egalitarian cultures encourage men to follow their vocational interests, while women's interests might be more directed towards more traditionally feminine activities. In areas where gender roles are not prescribed, women and men might be equally represented. OttHolland, Huang, Ryan, Elizondo, \& Wadlington (2013) found that connections between personality and vocational interests were less visible in collectivistic cultures. Contrary to their expectations, results also indicated gender differences might be existent in egalitarian cultures.

\section{Models of Vocational Interests}

The most esteemed model of vocational interests is the RIASEC model (Holland, 1997). It examines the linkages between individuals and their environments. Individuals prefer work activities and work environments that fit their personality traits, competencies, life goals and values (Lechner, Sortheix, Obschonka, \& Salmela-Aro, 2018). According to Holland (1997), six types of individuals and environments are: realistic ( $\mathrm{R}$ - working with things and gadgets), investigative (I - scientific work), artistic (A - aesthetic interests and self-expression), social ( $\mathrm{S}$ - people contact and helping professions), enterprising ( $\mathrm{E}$ - entrepreneurship and the corporate world), and conventional ( $\mathrm{C}$ - office work and well-structured tasks). Usually interest types are depicted in a hexagon form. The closer different types are to each other in a hexagon, the more related they are conceptually and 
empirically (Babarović et al., 2019). Despite the general support, cross-cultural studies of the Holland's hexagonal structure of types showed to be ambiguous in a sense that it did not fit the data well for non-US samples (Vardarlı et al., 2017; OttHolland et al., 2013).

In this study the Contextual Model of Vocational Interests (Ochnik, 2017) has been applied. The instability of vocational interests constituted the fundamental premise of the model. The intensity of the interests may be shaped by a broad spectrum of cultural factors (the most external layer), such as culture's gender dimension or social expectations, in particular in social gender roles performed by women and men of various ages. The model also emphasizes the role of individual factors, such as personality or entrepreneurial attitude, in shaping vocational interests and reaction to socio-cultural determinants (Ochnik, 2018). The Model of Vocational Interests introduces the concept of the vocational social clock, by presenting the dynamics of vocational preferences in regard to age and gender. Age and gender are determined by sociocultural factors, especially by social roles, particularly in prosocial and leadership vocational interests (Ochnik, 2017; Ochnik \& Rosmus, 2016). This study aims to examine the cultural context of vocational interests in Polish and Slovenian students in regard to gender.

In this article we aimed to expand the current understanding regarding the vocational interests variability across cultures and gender by analysing gender and nationality based differences among Polish and Slovenian samples. Since vocational interests are congruent within a particular field of study, it was crucial to compare young adults from different cultures (Poland and Slovenia) but within the same field of study. That allowed us to explore a sole culture's effect among students of Management. Exploring students in this particular field of study is of high importance, since those students are future European leaders (Ochnik \& Blažková, 2019). Gender was an additionally introduced variable, as gender inequality is a vital aspect related to leadership (Grant Thornton, 2017).

\section{Method}

The Vocational Potential Inventory by Ochnik \& Rosmus (2016) was used. The measurement consists of two sections: Skills and Traits. Respondents scored their skills on a 4-point scale, and traits on a 5-point scale. In total, the tool is comprised of 100 statements, 50 of these in the first section encompassing self-assessment of skills, and further 50 pertaining to traits in the second section.

On the basis of vocational tasks' division into two dimensions: Data/Ideas, and Things/People (Prediger, 1999), five key types of vocational preferences emerged: Pro-social, Creative, Technical, Leadership, and Methodical. The analysis of each of the types encompasses 10 skills and 10 traits. All scales scored a satisfactory Cronbach's $\alpha$, above 0.70: Pro-social - 0.703; Leadership - 0.75; Creative -0.79 ; Technical - 0.75; Methodical - 0.74, respectively (Ochnik \& Rosmus, 2016). The measurement turned out to be highly theoretically reliable with regard to personality traits and Holland's Model of vocational interests (Ochnik, 2017, 2018; Ochnik, Stala, \& Rosmus, 2018; Ochnik \& Rosmus, 2016). A conventional paper- 
and-pencil method was carried out in the study. Purposive sampling was used. Principles of voluntariness and anonymity were respected during the study.

\section{The sample}

The total of 226 students of Management, including Polish $(\mathrm{n}=108)$ and Slovenian $(\mathrm{n}=118)$ samples. The number of female students was $142(62 \%)$ and 88 (38\%) male students (see Table 1$)$.

Table 1

Descriptive Statistics of Vocational Interests Types with Regard to Gender and Nationality

\begin{tabular}{|c|c|c|c|c|c|c|}
\hline & Gender & Nationality & $\mathbf{n}$ & $\mathbf{M}$ & SD & Sten \\
\hline \multirow{4}{*}{ Pro-social } & Women & \multirow{2}{*}{ Polish } & 68 & 72.01 & 9.01 & 8 \\
\hline & Men & & 40 & 69.52 & 8.37 & 7 \\
\hline & Women & \multirow{2}{*}{ Slovenian } & 74 & 71.27 & 8.44 & 7 \\
\hline & Men & & 44 & 68.27 & 10.04 & 7 \\
\hline \multicolumn{3}{|l|}{ Total } & 226 & 70.60 & 8.98 & 7 \\
\hline \multirow{4}{*}{ Leadership } & Women & \multirow{2}{*}{ Polish } & 68 & 63.66 & 8.30 & 5 \\
\hline & Men & & 40 & 67.82 & 8.49 & 6 \\
\hline & Women & \multirow{2}{*}{ Slovenian } & 74 & 65.05 & 9.22 & 5 \\
\hline & Men & & 44 & 65.16 & 9.33 & 5 \\
\hline \multicolumn{3}{|l|}{ Total } & 226 & 65.15 & 8.90 & 5 \\
\hline \multirow{4}{*}{ Creative } & Women & \multirow{2}{*}{ Polish } & 68 & 63.35 & 10.08 & 5 \\
\hline & Men & & 40 & 64.92 & 9.20 & 5 \\
\hline & Women & \multirow{2}{*}{ Slovenian } & 74 & 61.05 & 8.24 & 5 \\
\hline & Men & & 44 & 63.14 & 10.13 & 5 \\
\hline \multicolumn{3}{|l|}{ Total } & 226 & 62.84 & 9.41 & 5 \\
\hline \multirow{4}{*}{ Technical } & Women & \multirow{2}{*}{ Polish } & 68 & 56.38 & 7.77 & 3 \\
\hline & Men & & 40 & 59.78 & 7.49 & 3 \\
\hline & Women & \multirow{2}{*}{ Slovenian } & 74 & 59.34 & 7.40 & 4 \\
\hline & Men & & 44 & 60.04 & 6.65 & 4 \\
\hline \multicolumn{3}{|l|}{ Total } & 226 & 58.66 & 7.50 & 3 \\
\hline \multirow{4}{*}{ Methodical } & Women & \multirow{2}{*}{ Polish } & 68 & 61.46 & 8.28 & 5 \\
\hline & Men & & 40 & 62.87 & 7.34 & 5 \\
\hline & Women & \multirow{2}{*}{ Slovenian } & 74 & 61.65 & 7.63 & 5 \\
\hline & Men & & 44 & 60.89 & 7.64 & 5 \\
\hline \multicolumn{3}{|l|}{ Total } & 226 & 61.68 & 7.76 & 5 \\
\hline
\end{tabular}




\section{Results}

SPSS 25 software was applied for the purpose of statistical analysis. Variables conformed to the fundamental premises of parametric tests regarding normal distribution and homogeneity of variance. Statistical analysis was applied in three steps. The first step referred to differences in the Polish $(\mathrm{N}=108)$ and Slovenian $(\mathrm{N}=118)$ samples with regard to gender. The second step challenged the effects of gender, nationality and gender $\times$ nationality within the total sample $(\mathrm{N}=226)$. The third step aimed to reveal cluster analysis.

The Kruskal-Wallis $\mathrm{H}$ test was performed to reveal the gender differences in vocational interests in the Polish and Slovenian samples. Polish male students scored higher in leadership vocational interests $\left(\mathrm{M}_{\text {rank }}=65.04\right)$ compared to Polish female students $\left(\mathrm{M}_{\text {rank }}=48.95\right)$, as the analysis of Kruskal-Wallis test showed, $\chi^{2}(1$, $\mathrm{N}=108)=6.64, p=.010$. Polish male students were also more into technical interests $\left(\mathrm{M}_{\mathrm{rank}}=63.48\right)$ compared to Polish female peers $\left(\mathrm{M}_{\mathrm{rank}}=49.89\right), \chi^{2}(1, \mathrm{~N}=118)=4.79$, $p=.030$. There were no significant differences in vocational interests between Slovenian students with regard to gender $(p>.05)$ and between Polish students in pro-social, creative and methodical types. (Figure 1)

In order to analyze the main effects of gender, nationality, and gender-nationality interaction for the pro-social, leadership, creative, technical, and methodical type of vocational interests a two-way ANOVA was carried out.

\section{Pro-Social Type}

Gender effect is statistically significant as shown by a two-way ANOVA, F (1, $222)=4.97, \chi^{2}=.022, p=.027$. The strength of this effect is weak. Female students rated their pro-social interests higher than male students did. The nationality effect

Figure 1

Mean ranks of Pro-social, Leadership, Creative, Technical, and Methodical Vocational Interests in Polish and Slovenian Students of Management with Regard to Gender

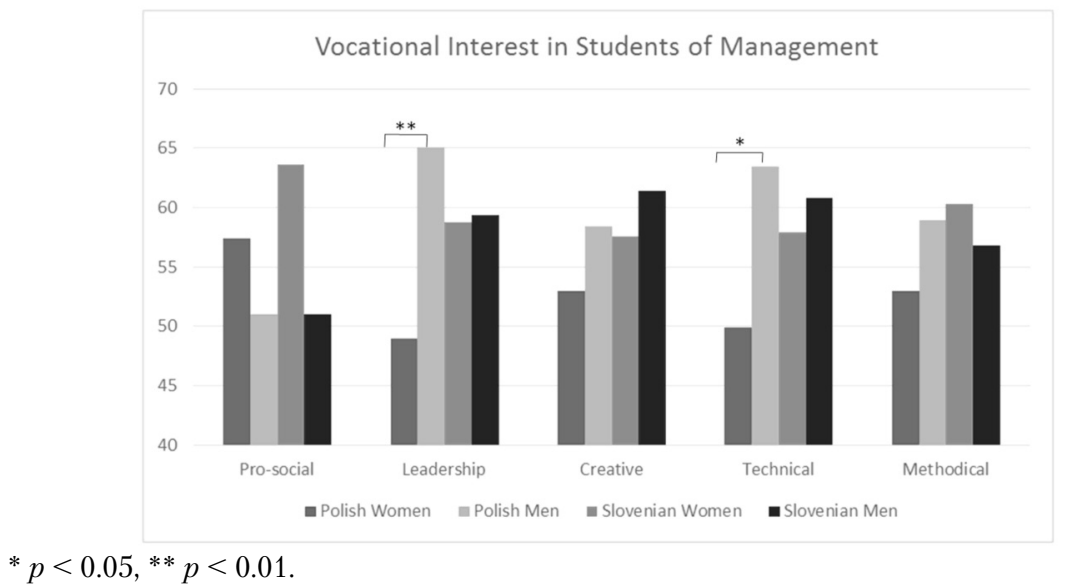


as well as the gender-nationality interaction turned out to be insignificant $(p>.05)$ (Figure 2).

\section{Leadership type}

A two-way ANOVA showed that gender effect, nationality effect, as well as the gender-nationality interaction for the leadership type of vocational interests, turned out to be insignificant $(p>.05)$.

\section{Creative type}

A two-way ANOVA showed that gender effect, nationality effect, as well as the gender-nationality interaction for the creative type of vocational interests, turned out to be insignificant $(p>.05)$.

\section{Technical type}

Gender effect is statistically significant, as shown by a two-way ANOVA, F (1, $222)=4.05, \chi^{2}=.018, p=.045$. The strength of this effect is weak. Male students rated their leadership interests higher than female students did. The nationality effect, as well as the gender-nationality interaction, turned out to be insignificant $(p>.05)$ (Figure 3).

\section{Methodical type}

A two-way ANOVA showed that gender effect, nationality effect, as well as the gender-nationality interaction for the methodical type of vocational interests, turned out to be insignificant $(p>.05)$.

Figure 2

Two-Way Analysis of Variance of Pro-Social Vocational Interests by Gender and Nationality

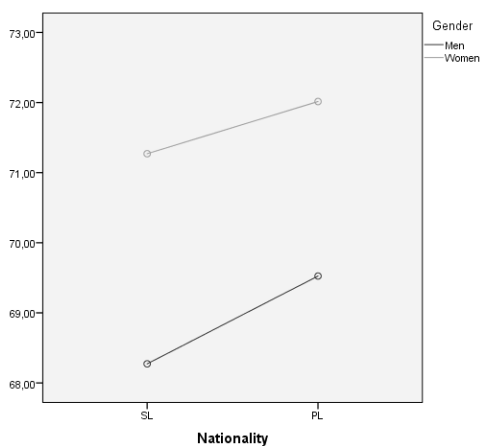

Figure 3

Two-Way Analysis of Variance of Leadership Vocational Interests by Gender and Nationality

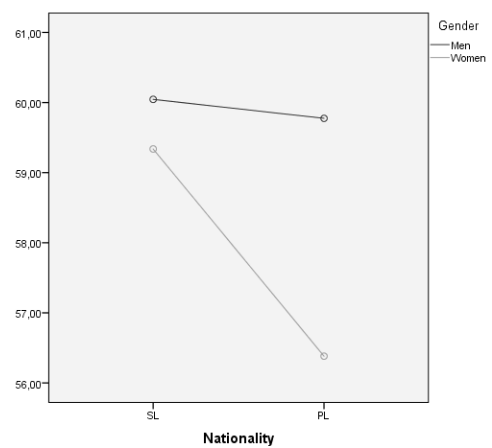


The two-step cluster analysis has been conducted as to reveal homogeneity of groups. The Silhouette measure of cohesion and separation revealed fair fit (.40). The analysis showed three clusters. The ratio of size was 1.24 that denotes a similar size of clusters. Gender turned out to be the most important variable, the second variable was nationality. The technical type proved to be the most important variable type of vocational interests.

Group 1 consisted of Slovenian female students, with the weakest creative but medium technical, pro-social, leadership and methodical interests (compared to other groups). Group 2 consisted of Polish female students with the strongest prosocial but the weakest technical, leadership and methodical vocational interests. Group 3 consisted of male students (both Polish and Slovenian), with the strongest technical, creative, leadership and methodical but the weakest pro-social vocational interests (see Table 2, Figure 4).

\section{The highest value of variable in the clusters}

As the distribution of vocational interests was within one standard deviation, the one-way ANOVA has been carried out in order to confirm the significance of differences in vocational interests between clusters. It showed that the technical type differentiates significantly between clusters, $\mathrm{F}(2,223)=4.77, p=.009$. Tukey's HSD post-test revealed that Group 1 and Group 3 scored significantly higher in technical interests compared to Group 2. There are no significant differences between Group 1 and Group 3 in technical interests. The pro-social, creative, leadership and methodical types of vocational interests proved not to differentiate significantly among the emerged clusters $(p>.05)$.

To conclude, the cluster analysis allowed three groups to be identified: Slovenian Women, Polish Women and Men. Group 1 was comprised of Slovenian female students with technical interests higher than in Polish female students in

Table 2

Descriptive Statistics of Two-Step Cluster Analysis

\begin{tabular}{|c|c|c|c|}
\hline Input variables & $\begin{array}{c}\text { Group 1 } \\
\mathrm{N}=\mathbf{7 4}(32,7 \%)\end{array}$ & $\begin{array}{c}\text { Group } 2 \\
\mathrm{~N}=68(30.1 \%)\end{array}$ & $\begin{array}{c}\text { Group } 3 \\
\mathrm{~N}=84(37.2 \%)\end{array}$ \\
\hline Gender & Women $(100 \%)$ & Women $(100 \%)$ & Men (100\%) \\
\hline Nationality & Slovenian $(100 \%)$ & Polish (100\%) & $\begin{array}{c}\text { Slovenian }(52.4 \%) \\
\text { Polish }(47.6 \%)\end{array}$ \\
\hline Technical & 59.34 & 56.38 & 59.92 \\
\hline Pro-social & 71.27 & 72.01 & 68.87 \\
\hline Creative & 61.05 & 63.35 & 63.99 \\
\hline Leadership & 65.05 & 63.66 & 66.43 \\
\hline Methodical & 61.65 & 61.46 & 61.88 \\
\hline
\end{tabular}

Note. Input Variables showed in order of Variable Importance. 
Figure 4

The Results of Cluster Analysis with Regard to Gender, Nationality and Vocational Interests

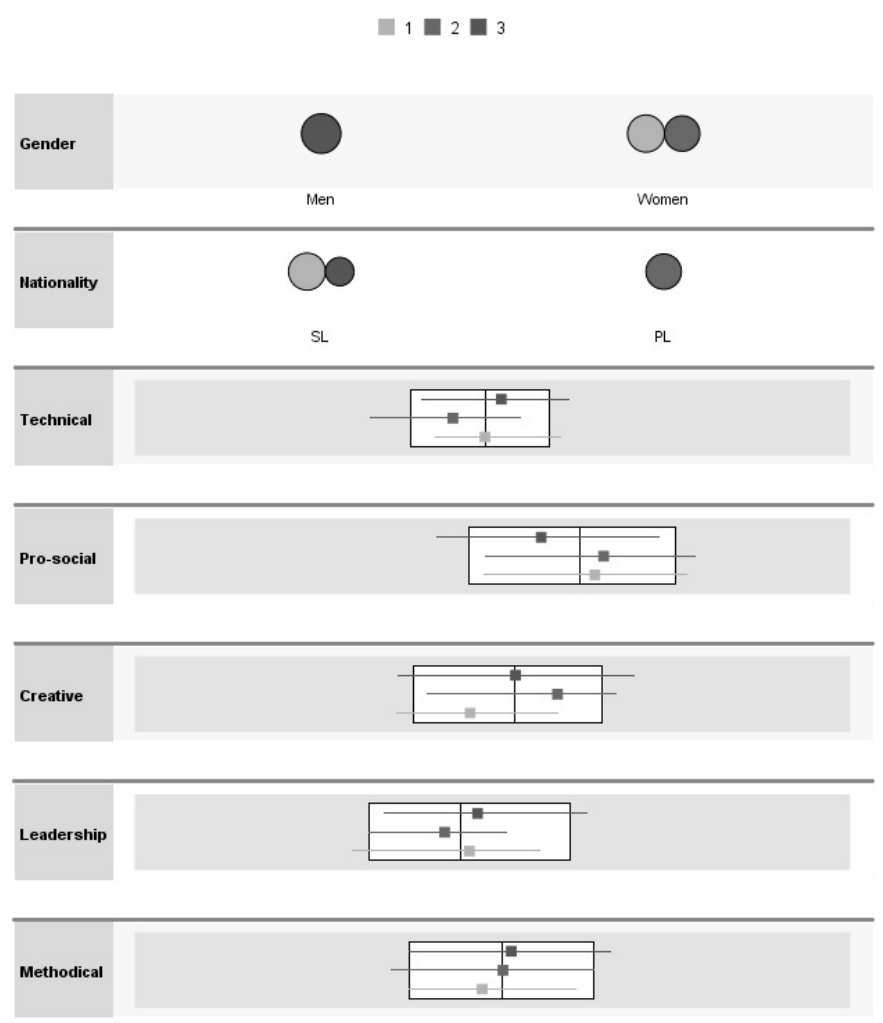

Group 2 and similar to male students in Group 3. Polish female students scored lowest in technical vocational interests compared to Slovenian female students and male students.

\section{Discussion}

This study investigated the characteristic of vocational interests in Polish and Slovenian students of Management with regard to gender and nationality. This was the first study to investigate vocational interests in the Slovenian sample of Management students. In addition, this was the first study to analyze vocational interests among Polish and Slovenian students in order to study gender differences.

The results showed that Management students have high pro-social, and medium leadership, creative and methodical vocational interests, while the technical interests are at a low level. That means that students are only slightly interested in using tools, diagnosing problems and searching for practical solutions. 
Simultaneously, they are strongly interested in consulting, initiating contacts or solving interpersonal conflicts.

In terms of gender differences in vocational interests in Polish and Slovenian samples, it was shown that Polish male students scored higher in leadership vocational interests compared to Polish female students. Polish male students were also more into technical interests compared to Polish female peers. However, there were no significant differences in vocational interests among Slovenian students with regard to gender and among Polish students in pro-social, creative and methodical types. This is in line with meta-analytic research findings that indicate a decrease in gender differences in vocational interests across cohorts of individuals born in latest decades (Bubany \& Hansen, 2011; Hansen, 1988; Mustata, 2014).

\section{Leadership}

It is noteworthy that the sample as a whole showed average interest in leadership, while being more pro-social. This means that Management students perceive their skills in giving commands, influencing others, and decision-making lower than helping others, mitigating conflicts, or caring for others. They correspondingly describe themselves as friendly and cooperative rather than energetic, ambitious or self-confident. Leadership interests are also explained by personality (high conscientiousness, low neuroticism and high extraversion) and strong entrepreneurial attitude orientation (Ochnik, 2018). Additionally, previous research within over 9,000 population showed that in early adulthood (20-24 years) leadership interests are weaker compared to age of intensive professional activity (30-54 years) in men. Although the difference in young men and women was not pronounced, in older male groups leadership interests were distinctively higher than in older female groups but remained stable in older female groups (Ochnik, 2018). This observation finds confirmation in the recent study by Wetzel et al. (2017) on normative narcissism revealing that nowadays students, in comparison with their peers in the 1990s, 2000s, and 2010s, presented not only lower levels of normative narcissism but also an acute drop in leadership interests almost year by year. That means students in 2018 estimated their abilities and leadership interest much lower compared to students in previous decades.

Therefore, average leadership interests in Management students from different countries might be explained by broader social generational change. Young adults, even planning their career in Management, have stronger pro-social interests (orientation for people) than leadership. Nevertheless, it remains in congruence with the skills expected at the labor market (World Economic Forum, 2016), as coordination with others is still among the top five most effective skills.

\section{Gender $\mathcal{E}$ Nationality}

The gender differences were more pronounced in the Polish group, with Polish female students having stronger pro-social interests compared to Polish male students, and Polish male students were more interested in leadership. Female students 
in general had higher pro-social and lower technical interests. Therefore, the gender effect reflected the stereotypical gender role, women - people orientated and men - things orientated (Lippa, 2001). This is consistent with other research (Vock et al., 2013; Mustata, 2014; Ion et al., 2019; Lawson, Leeb, Crouter, \& McHale, 2018) by implying that women and men, especially in Polish society, might be encouraged to follow vocational patterns congruent with social norms.

On the other hand, no statistical differences occurred in the Slovenian sample. This is in line with a report on gender equality in Slovenia by the Ministry of Labour, Family, Social Affairs and Equal Opportunities (Möller-Slawinski \& Calmbach, 2016). Although young women and men (up to 29 years) exerted many stereotypical role expectations for the opposite gender, ambitiousness and good education were expected features for men as well as for women. Slovenian young men expect women to be strong, independent, assertive, self-confident and equal opportunities oriented. Slovenian young women, however, expect men to possess mainly traditionally masculine qualities (being athletic, adventurous and possessing the qualities of a gentleman). This finding might explain why women in Slovenian society are not discouraged from gender non-stereotypical vocations. Alternatively, Slovenian men are still encouraged to follow vocational patterns congruent with social norms. This finding is accordant with findings by Wood \& Eagly (2010) who showed that in egalitarian societies (such as Slovenian) women are not restrained from certain male-dominated careers, while this is not necessarily the case for men in female dominated professions.

The nationality effect turned out to be insignificant. However, there were three clusters revealed, showing differentiation with regard to nationality. The clusters consisted of a Slovenian female group, a Polish female group and a male group. That means that cultural differences are stronger in the female group compared to the male group. Clustering revealed the male group having the strongest technical interests and Polish women the weakest. On the other hand, the male group is showing the weakest pro-social interests while Polish women are having the strongest pro-social interests.

Therefore, it can be concluded that the cultural factor is stronger in women. The group of male students was more homogenous compared to female students. Polish female students of Management emphasize stereotypical gender roles, and it can be noticed that the cultural factor affects this group the most and can manifest in pursuing career choices. It can reflect strong gender social roles in Polish society, as they are pronounced even in female students of non-stereotypical major. On the other hand, gender social norms are less evident in the Slovenian sample. The Slovenian group of women is showing the weakest creative vocational interests, while Polish women are having the strongest creative interests.

Nevertheless, the strongest technical interests were found in the male group that depicts gender issues in STEM. As vocational interests are a better predictor of future career than personality traits (Stoll et al., 2017), the gender gap in STEM might not diminish that quickly, especially in Poland.

The research showed the specifics of vocational interests in students of Management. Gender differences turned out to be stronger than cultural but the 
cultural factor was more pronounced in women. Therefore, vocational interests of female students are more prone to cultural norms.

\section{Limitations of the Study and Implications for Further Research}

The potential limitations of the research include sampling shortcomings and the use of self-report measures. A bigger sample could provide better opportunities for generalization of research results in Polish and Slovenian national contexts. Secondly, instead of purposive sampling, random sampling could provide insights of vocational interests by students who currently declined to take part in the survey. Thus, it is advised to include more Management students from Polish and Slovenian subsamples in future research. In addition, self-report measures might lead to either under-reporting or over-reporting of some vocational interests. It would also be interesting to analyse vocational interests of other (STEM and nonSTEM) students in Poland and Slovenia in order to promote gender diversity and increase the number of female students enrolled in STEM disciplines (Botella et al., 2019).

\section{References}

Almeida, P. I. L., Ahmetoglu, G., \& Chamorro-Premuzic, T. (2014). Who wants to be an entrepreneur? The relationship between vocational interests and individual differences in entrepreneurship. Journal of Career Assessment, 22(1), 102-112. doi:10.1177/1069072713492923

Atitsogbe, K. A., Moumoulab, I. A., Rochata, S., Antoniettia, J.-P., \& Rossier, J. (2018). Vocational interests and career indecision in Switzerland and Burkina Faso: Cross-cultural similarities and differences. Journal of Vocational Behavior, 107, 126-140.

Babarović, T., Dević, I., \& Burušić, J. (2019). Fitting the STEM interests of middle school children into the RIASEC structural space. International Journal for Educational and Vocational Guidance, 19, 111-128. doi:10.1007/s10775-018-9371-8

Bagheri, A., Akmaliah, Z., \& Pihie, L. (2014). The moderating role of gender in shaping entrepreneurial intentions: Implications for vocational guidance. International Journal for Educational and Vocational Guidance, 14, 255-273. doi:10.1007/s10775-014-9269-z

Bergner, S., Kanape, A., \& Rybnicek, R. (2019). Taking an interest in taking the lead: The influence of vocational interests, leadership experience and success on the motivation to lead. Applied Psychology: An International Review, 68(1), 202-219. doi:10.1111/apps.12150

Botella, C., Rueda, S., López-Iñesta, E., \& Marzal, P. (2019). Gender diversity in STEM disciplines: A multiple factor problem. Entropy, 21(1), 30. doi:10.3390/e21010030

Bubany, S. T., \& Hansen, J.-I. C. (2011). Birth cohort change in the vocational interests of female and male college students. Journal of Vocational Behavior, 78, 59-67.

Chamorro-Premuzic, T. (2011). Personality and individual differences (2nd ed.). Oxford, UK: WileyBlackwell.

Grant Thornton. (2017). Grant Thornton UK LLP Annual Report 2017. Retrieved from https://www.grantthornton.co.uk/globalassets/1.-member-firms/united-kingdom/pdf/documents/grant-thornton-uk-annual-report-2017.pdf 
Hirschi, A. (2010). Individual predictors of adolescents' vocational interest stabilities. International Journal for Educational and Vocational Guidance, 10, 5-19. doi:10.1007/s10775-009-9171-2

Holland, J. L. (1997). Making vocational choices: A theory of vocational personalities and work environments (3rd ed.). Odessa, FL: Psychological Assessment Resources.

Ion, A., Nye, C.D., \& Iliescu, D. (2019). Age and gender differences in the variability of vocational interests. Journal of Career Assessment, 27(1), 97-113. doi:10.1177/1069072717748646

Lawson, K. M., Leeb, B., Crouter, A. C., \& McHale, S. M. (2018). Correlates of gendered vocational development from middle childhood to young adulthood.Journal of Vocational Behavior, 107, 209221. doi:10.1016/j.jvb.2018.05.002

Lechner, C. M., Sortheix, F. M., Obschonka, M., \& Salmela-Aro, K. (2018). What drives future business leaders? How work values and gender shape young adults' entrepreneurial and leadership aspirations. Journal of Vocational Behavior, 107, 57-70. doi:10.1016/j.jvb.2018.03.004

Lippa, R. (2001). On deconstructing and reconstructing masculinity-femininity. Journal of Research in Personality, 35, 168-207.

Low, K. S., \& Rounds, J. (2007). Interest change and continuity from early adolescence to middle adulthood. International Journal for Educational and Vocational Guidance, 7, 23-36. doi:10.1007/s10775-006-9110-4

Lubinski, D. (2000). Scientific and social significance of assessing individual differences: "Sinking shafts at a few critical points”. Annual Review of Psychology, 51, 405-444. doi:10.1146/ annurev.psych.51.1.405

Lubinski, D., Benbow, C. P., \& Ryan, J. (1995). Stability of vocational interests among the intellectually gifted from adolescence to adulthood: A 15-year longitudinal study. Journal of Applied Psychology, 80(1), 196. doi:10.1037/0021-9010.80.1.196

Möller-Slawinski, H., \& Calmbach, M. (2016). Gender equality in Slovenia. Ljubljana: Ministry of Labour, Social Affairs and Equal Opportunities. Retrieved from http://www.mddsz.gov.si/fileadmin/ mddsz.gov.si/pageuploads/dokumenti_pdf/enake_moznosti/NFMPublikacijaRaziskavaAN.pdf

Mustata, A.-E. (2014). The role of gender in the formation of vocational interests and career orientation in adolescence. Procedia - Social and Behavioral Sciences, 127, 240-244.

Nagy, G., Trautwein, U., Baumert, J., Köller, O., \& Garrett, J. (2006). Gender and course selection in upper secondary education: Effects of academic self-concept and intrinsic value. Educational Research and Evaluation, 12, 323-345.

Nye, C. D., Su, R., Rounds, J., \& Drasgow, F. (2012). Vocational interests and performance: A quantitative summary of over 60 years of research. Perspectives on Psychological Science, 7(4), 384-403. doi:10.1177/1745691612449021

Ochnik, D. (2017). Prospołeczne preferencje zawodowe a społeczny zegar zawodowy kobiet i m żczyzn. [Prosocial vocational interests and social vocational clock]. Czasopismo Psychologiczne Psychological Journal (CPPJ), 23(2), 241-247. doi:10.14691/CPPJ.23.2.241

Ochnik, D. (2018). Entrepreneurial attitude and personality as predictors of leadership vocational interests in men and women. In Innovation Management, Entrepreneurship and Sustainability (IMES 2018) - Proceedings of the 6th International Conference (pp. 857-866). Prague, Czech Republic: University of Economics. Retrieved from: https://imes.vse.cz/wp-content/uploads/2018/07/Conference_Proceedings_IMES_2018.pdf

Ochnik, D., \& Blažková, I. (2019, July 1-3). Vocational interests in polish and czech students of management with regard to gender. Paper presented at 11th International Conference on Education and New Learning Technologies, Spain. doi:10.21125/edulearn.2019.1287 
Ochnik, D., \& Rosmus, R. (2016). Preferencje zawodowe młodych Polek i Polaków. Vocational preferences of young Polish men and women. HRM, 6(113), 43-56.

Ochnik, D., Stala, M., \& Rosmus, R. (2018). Skala prospołecznych preferencji zawodowych. Czasopismo Psychologiczne - Psychological Journal (CPPJ), 24(1), 151-158. doi:10.14691/CPPJ.24.1.151

Ott-Holland, C. J., Huang, J. L., Ryan, A. M., Elizondo, F., \& Wadlington, P. L. (2013). Culture and vocational interests: The moderating role of collectivism and gender egalitarianism. Journal of Counseling Psychology, 60, 569-581. doi:10.1037/a0033587

Paessler, K. (2015). Sex differences in variability in vocational interests: Evidence from two large samples. European Journal of Personality, 29, 568-578. doi:10.1002/per.2010

Prediger, D. J. (1999). Basic structure of work-relevant abilities. Journal of Counseling Psychology, 42, $178-184$.

Schultz, L.-H., Connolly, J. J., Garrison, S. M., Leveille, M. M., \& Jackson, J. J. (2017). Vocational interests across 20 years of adulthood: Stability, change, and the role of work experiences. Journal of Research in Personality, 71, 46-56. doi:10.1016/j.jrp.2017.08.010

Stoll, G., Rieger, S., Lüdtke, O., Nagengast, B., Trautwein, U., \& Roberts, B. W. (2017). Vocational interests assessed at the end of high school predict life outcomes assessed 10 years later over and above IQ and Big Five personality traits. Journal of Personality and Social Psychology, 113(1), 167-184. doi:10.1037/pspp0000117

Stone, M. J., Padron, T. C., Wray, M. L., La Lopa, J. M., \& Olson, E. D. (2017). Career desires and expectations of event management students. Journal of Hospitality and Tourism Management, 32, 45-53. doi:10.1016/j.jhtm.2017.04.005

Su, R., Rounds, J., \& Armstrong, P. I. (2009). Men and things, women and people: A meta-analysis of sex differences in interests. Psychological Bulletin, 135, 859-884.

Tracey, T. J., Allen, J., \& Robbins, S. B. (2012). Moderation of the relation between person-environment congruence and academic success: Environmental constraint, personal flexibility and method. Journal of Vocational Behavior, 80(1), 38-49.

Tracey, T. J. G., \& Robbins, S. B. (2006). The interest-major congruence and college success relation: A longitudinal study. Journal of Vocational Behavior, 69, 64-89.

Van Iddekinge, C. H., Roth, P. L., Putka, D. J., \& Lanivich, S. E. (2011). Are you interested? A metaanalysis of relations between vocational interests and employee performance and turnover.Journal of Applied Psychology, 96, 1167-1194. doi:10.1037/ a0024343

Van Iddekinge, C. H., Putka, D. J., \& Campbell, J. P. (2011). Reconsidering vocational interests for personnel selection: The validity of an interest-based selection test in relation to job knowledge, job performance, and continuance intentions. Journal of Applied Psychology, 96(1), 13. doi: $10.1037 / \mathrm{a} 0021193$

Vardarlı, B., Özyürek, R., Wilkins-Yel, K. G., \& Tracey, T. J. G. (2017). Examining the structure of vocational interests in Turkey in the context of the personal globe model. International Journal for Educational and Vocational Guidance, 17, 347-359. doi:10.1007/s10775-016-9338-6

Vock, M., Köller, O., \& Nagy, G. (2013). Vocational interests of intellectually gifted and highly achieving young adults. British Journal of Educational Psychology, 83, 305-328.

Volodina, A., \& Nagy, G. (2016). Vocational choices in adolescence: The role of gender, school achievement, self-concepts, and vocational interests. Journal of Vocational Behavior, 95-96, 58-73. doi:10.1016/j.jvb.2016.07.005 
Wetzel, E., Brown, A., Hill, P. L., Chung, J. M., Robins, R. W., \& Roberts, B. W. (2017). The Narcissism epidemic is dead; long live the Narcissism epidemic. Psychological Science, 28(12), 1833-1847. doi:10.1177/0956797617724208

Wille, B., Tracey, T. J., Feys, M., \& De Fruyt, F. (2014). A longitudinal and multi-method examination of interest-occupation congruence within and across time. Journal of Vocational Behavior, 84(1), 59-73.

Wood, W., \& Eagly, A. H. (2010). Gender. In S. T. Fiske, D. T. Gilbert, \& G. Lindzey (Eds.), Handbook of social psychology (pp. 629-667). New York: Wiley.

World Economic Forum. (2016). Future of Jobs Report. Retrieved from http://www3.weforum.org/docs/WEF_Future_of_Jobs.pdf

Dominika Ochnik - Assistant Professor, Department of Psychology, University of Opole (Opole, Poland), PhD.

Research Area: psychology of work (vocational interests, entrepreneurial attitude), psychological aspects of singlehood.

E-mail: dominika.ochnik@uni.opole.pl

Ana Arzenšek - Head of Department, Assistant Professor, Faculty of Management, University of Primorska (Koper, Slovenia), PhD.

Research Area: change management, vocational interests and work motivation.

E-mail: ana.arzensek@fm-kp.si 


\title{
Профессиональные интересы польских и словенских студентов, изучающих менеджмент
}

\author{
Д. Очника , А. Арзеншек \\ ${ }^{a}$ Опольский университет, 45-052, Польша, Ополье, пл. Стажица, 1 \\ ${ }^{b}$ Приморский университет, 6000, Словения, Копер, ул. Цанкарьева, 5
}

\begin{abstract}
Резюме
Поскольку профессиональные интересы являются более сильным предиктором будущего профессионального успеха, чем черты личности или IQ, важно иметь представление о профессиональных интересах будущих руководителей. Целью настоящей статьи было подробное описание актуальных представлений о вариативности профессиональных интересов у представителей разных культур и различной гендерной принадлежности посредством анализа гендерных и национальных различий между польской и словенской выборками. В исследовании приняли участие 226 студентов, обучающихся на факультетах менеджмента в Польше и Словении. В исследовании применялся опросник Vocational Potential Inventory. Гендерные различия были более явными в польской группе: у польских женщин наблюдаются более выраженные просоциальные интересы по сравнению с польскими мужчинами, в то время как польские мужчины проявляли бо́льшую заинтересованность в лидерстве. В словенской выборке не было выявлено статистически значимых различий в профессиональных интересах. В целом, у студенток более выражены просоциальные интересы и менее выражены технические интересы. Таким образом, гендерный эффект отражает стереотипную гендерную роль: женщины ориентированы на людей, а мужчины - на предметы. Что касается эффекта национальности, было выявлено три кластера с дифференциацией в отношении национальности. Кластеры были представлены словенской женской группой, польской женской группой и мужской группой. Это означает, что культурные различия ярче выражены в женской группе по сравнению с мужской. Кластеризация показала, что самые сильные технические интересы наблюдаются у представителей мужской группы, и слабее всего они выражены у польских женщин. Сформулированы выводы на основании полученных результатов.
\end{abstract}

Ключевые слова: профессиональные интересы, студенты, менеджмент, гендер, национальность, культура, Vocational Potential Inventory, социальные нормы, интерес к лидерству, технический интерес, Польша, Словения.

Очник Доминика - доцент, факультет психологии, Опольский университет (Ополье, Польша), кандидат психологических наук.

Сфера научных интересов: психология труда (профессиональные интересы, предпринимательские отношения), психологические аспекты жизни вне брака.

Контакты: dominika.ochnik@uni.opole.pl

Арзеншек Ана - доцент, заведующая кафедрой, факультет менеджмента, Приморский университет (Копер, Словения), кандидат психологических наук.

Сфера научных интересов: управление изменениями, профессиональные интересы и мотивация к работе.

Контакты: ana.arzensek@fm-kp.si 